\title{
The Effects of Student-Consumerism on Discipline Specific Teaching Practices: A Comparison of Education and Law
}

\section{Tawney Bennett ${ }^{1}$}

Student consumerism in the Higher Education (HE) sector continues to stimulate critical academic commentary about the consequences of marketisation. Although much of the debate focuses on the effects that consumerism has on student achievement, little empirical research has analysed the effect that consumerism has on teaching and associated practices from an academic standpoint. Moreover, the disparities between how differing disciplines perceive student consumerism, and the varying effects that this has depending on the academic discipline, remain under-researched. This paper examines findings from eight in-depth interviews that sought to investigate the effects of studentconsumerism on the teaching practices of academics from the departments of education and law, in one post-1992 university in England. It finds that perceptions of student-consumerism differ between the disciplines of education and law. One of the key arguments for this finding is that academics in the field of education are accustomed to a regulatory environment, whereas law academics are acclimatised to greater levels of autonomy. A further argument put forward by this paper is that the stark contrast in graduate salary expectations between education and law, may also impact upon student consumerism. This article recommends that further research is sought in the form of an in-depth, qualitative study of the impact of student satisfaction accountability on academic staff members' experience of teaching in HE.

\footnotetext{
${ }^{1}$ Tawney Bennett, Lecturer in Law at University of Salford, t.I.bennett@salford.ac.uk
} 
Furthermore, interdisciplinary research into the effects of consumerism on teaching practices should be conducted, as the current study highlighted some interesting differences between two departments. Finally this article recommends that further research is needed to clarify how students quantify value for money in a higher education context and further.

\section{Part I}

\section{Introductory Background: The Changing Landscape of Higher}

\section{Education}

Traditionally viewed as elitist and exclusive, the higher education system faced several criticisms in the 1960s (Amis, 1960; Trow, 1973; Bathmaker, 2003). A university education was seen to be reserved for those from middle-class backgrounds, who were young and academically successful and came from grammar and public schools (Bathmaker, 2003). Furthermore, the growing populist opinion that education and training were key to economic growth, led to petition for change (Ashton and Green, 1996; Brown and Lauder; 1995). Moreover, the Conservative Conference Party had recommended that the Government invest in the future through the mass expansion of higher education (Gosden, 1983). As a result of these demands, the Government appointed the Robbins Committee to investigate higher education practices and advise which principles should underpin long-term policy (Robbins, 1963). The conclusions of the report propelled the remarkable transformation in university participation rates, which saw student-intake numbers double between the years of 1963 and 1970 (Walford, 1991). It advocated for the continual expansion of the higher education system to allow for all those who qualified and wished to attend university to do so (Robbins, 1963). The government 
action following the report led to many new universities being built and successfully achieved its aims of mass expansion, amongst other things (Moser, 1988).

However, the Robbins committee's efforts were criticised for a lack of consideration of the implications associated with mass expansion, such as student finance (Moser, 1988). Despite this, many academics consider the various government policies introduced in the 1990s to be the most significant catalysts of consumerism (Molesworth, Scullion and Nixon, 2011; Brown, 2015), particularly the introduction of tuition fees (Farrell and Tapper, 1992; Brown and Carasso, 2013; McGettigan, 2013; Palfraymen and Tapper, 2014; 2016). It is on this foundation of consumerism, largely created by the introduction of tuition fees, that the student-consumer concept has been embraced (Molesworth, Scullion and Nixon, 2011).

Students were initially identified as consumers in the 1990s in the Dearing Report (1997). The report was commissioned to negate the financial crisis caused by the underfunding and expansion of higher education following the Robbins Report (Watson and Taylor, 1998). Since then, and as a result of tuition fee increases, students are increasingly identified as 'university customers' more so than developing learners (Molesworth, Scullion and Nixon, 2011; Bunce, 2017). Bunce (2017) claims that a common complaint of students in UK universities today is "I'm paying $£ 9000$ a year for this!" which she states ameliorates traditional educational values. Instead, the attainment of a university degree is arguably likened to a financial transaction, whereby anything that does not directly link to their final award is disregarded (Bunce, 2017). Bunce (2017) bases such comments on her own extensive research into the student-consumer approach and its relationship with academic 
performance. She conducted a large-scale study, surveying 608 undergraduates in higher education throughout the UK, that positively contributed to an area on which little previous research had been conducted (Saunders, 2014; Tomlinson, 2017). Furthermore, Bunce openly acknowledges the limitations of her research, such as the subjectivity of the responses and the consequent reliance on participants self-reporting academic performance truthfully. She also proposes further lines of original research, such as investigating the attitudes of international students towards the cost of higher education.

Although the preceding reports each played a part in the transformation of the sector, the significant fee increases are arguably held most responsible for the shift in student mind-sets (Farrell and Tapper, 1992; Molesworth, Scullion and Nixon, 2011; Brown and Carasso, 2013; McGettigan, 2013; Palfraymen and Tapper, 2014; 2016; Bunce, 2017). Following the Browne review (2010), universities in England could increase their fees from $£ 3375$ to $£ 9,000$ per annum and more recently, $£ 9,250$ (Tomlinson, 2017). Lord Browne's original aim was to introduce competitive pricing into the marketisation of Higher Education, however in 2016 all but three of the top ninety institutions charged the maximum of $£ 9000$ (Parliament, 2018). As a result, students seek greater value for money from their university and universities are subjected to competitive pressures typical of the highly-marketised private sector (Woodall et al., 2014).

Despite the wealth of existing discourse on student-consumerism, the disparities between how differing disciplines perceive consumerism and the varying effects of the student-consumer mindset across disciplines, remain under-researched. Therefore, this paper seeks to investigate the effects of the student-consumer mindset on the teaching practices of academics from the departments of education and law, in a post-1992 university in England. The 
research adopts a qualitative approach, using in-depth interviews of selected academic staff members, to investigate this significant area of exploration.

This paper has effectively set the scene for the research in Part I by providing the background and rationale. Part II critically analyses the literature on student consumerism, with a focus on three key aspects namely whether students identify as consumers, what students consider to be value for money and the effects of consumerism on teaching practices. Part III of this article examines the methodology by explaining the sample size, rationale for selection and the data collection methods. Part IV provides a discussion of the results and triangulates the interview data with the existing literature on the student-consumer mindset. Finally, Part V concludes with appropriate recommendations for future practice and research.

\section{Part II}

\section{Are Students Consumers?}

As early as $400 \mathrm{BC}$, Socrates understood that likening students to consumers was a mistake (Angulo, 2016). However, whether the student is a customer, or should be viewed as such, is a long-standing debate (Olshavsky and Spreng, 1995; Pitman, 2000; Alford, 2002; Hom, 2002). Many academics have argued that the current managerial regime in universities promotes a culture where students simply seek to obtain a degree, rather than becoming lifelong learners or subject experts (Molesworth et al., 2009; Williams, 2010; Woodall, Hiller and Resnick, 2014). Conversely, others argue that students do not self-identify in this way, instead it is due to a label imposed by Government policy-makers (Saunders, 2014). This view was synthesised by an anonymous academic in The Guardian (2018) who remarked that students don't want to be passive 
consumers. However, as will be discussed later in this section, Saunders (2014) bases his claims on his own research which was undertaken in the US rather than in the UK. Although, the empirical work of Bunce (2017) was conducted in the UK in 2015 and resulted in similar findings, with students identifying more so as learners than consumers.

Molesworth et al. (2009) argue that a consumer culture exists within higher education institutions, which consequently decreases intellectual complexity in favor of student appeasement. They posit that such culture prevents the transformation of undergraduates into subject scholars equipped with skills such as critical thinking, and instead is focused on producing a happy customer. Molesworth et al. $(2009 ; 2010)$ write in depth about the marketisation of higher education and students as consumers, basing their comments on reputable data sources such as international academic perspectives, empirical research and critical accounts from experts.

Saunders (2014) undertook a large-scale research study into the extent to which students view themselves as consumers. He found that, contrary to the dominant ideology, the results suggested that most students did not express a consumer orientation. However, the study was undertaken in America which has a lengthier history of student tuition fees and marketisation (Angulo, 2016). Furthermore, Saunders' (2014) participants consisted of solely first-year students who arguably are less likely than any other year group to present a learner identity due to their grades typically not counting towards their degree and the length of distance until graduation (Trope and Liberman, 2010; Goodall, 2012). However, Bunce (2017) found that the students' year of study had no effect on a student's expression of a consumer orientation. This finding was validated in her empirical research. 
Bunce (2017) conducted her own large-scale study into learner attitudes in UK universities, focusing on whether students expressed a desire to obtain a degree, or to learn and read a subject. However, she does not state at which types of institution the studies were carried out, which may have relevance to the outcomes of the study (Lomas, 2007). Bunce (2017) found that consumer and learner identity were negatively correlated and that predictions about learner identity could be made from key variables such as degree classification aspirations, age and whether students volunteered for a specific role at university. Bunce (2017) claims that her findings suggest that the current climate promotes students as consumers of education rather than learners. However, she acknowledges that further research, specifically longitudinal study, ought to be sought into this topic to mitigate the effects of a consumerist culture.

Tomlinson (2017) claims that tuition fee increases have undoubtedly encouraged students to seek greater accountability from universities as to how their fee revenue is used. Although he does acknowledge that students remain conscious of their own responsibility to get as much out of their university experience as they can. Tomlinson (2017) conducted his own study in England to explore the effects of increased tuition fees on attitudes towards learning. The results mirrored those of Saunders' (2014) study, finding that students rejected the consumer label. However, Tomlinson's study was conducted on a much smaller scale than that of Bunce (2017), interviewing only 68 undergraduate students across seven UK institutions, who entered higher education between the years of 2011 and 2012. It is also important to note that September 2011 entrants would have paid $£ 3250$ tuition fees, whereas September 2012 entrants would have paid f9000, therefore creating the potential for inconsistent results between participants. 
Similar conclusions were presented by Williams (2013), who found that students were strongly opposed to the idea of being consumers. Her book provides an indepth socio-historical analysis of the commercialisation of the higher education sector. She draws on her own personal experience, examination of policy studies and extracts from a set of qualitative interviews to provide an account of the current and future state of consumerism in higher education institutions. However, Williams (2013) notes that students sometimes 'juggle complex identities'. She found that whilst students expressly declined certain consumerist elements such as viewing a degree as a financial transaction, they accepted others such as viewing university as a financial investment. Interestingly, Williams (2013) argues against the commonly held view that student-consumerism stems from the introduction of tuition fees and the subsequent fee increases (Farrell and Tapper, 1992; Brown and Carasso, 2013; McGettigan, 2013; Palfraymen and Tapper, 2014; 2016; Bunce, 2017). Instead, she claims that the shift in conceptualisation of students as learners to consumers is a result of changing social, economic and political attitudes which have moulded the public's understanding of the purpose of higher education (Williams, 2013). However, Williams (2013) bases her claims on data collected prior to the tuition fee increases from $f 3250$ to $f 9000$, which may largely affect the views of the interviewees and alter the outcomes of the research if it were repeated today.

Guilbault (2018) acknowledges the contradiction between academic integrity and providing high quality customer service. Conversely, she finds that students must be considered customers in the development of marketing strategy and illuminates the value in adopting a student as consumer approach (Maguad, 2007; Guilbault, 2018). Furthermore, Guilbault (2018), contrary to popular opinion (Molesworth, Nixon \& Scullion, 2009; Williams, 2010; Woodall, Hiller \& 
Resnick, 2014; Bunce, 2017), argues that treating students as customers does not mean that they must be given what they want. She adds that Gordon's (1909) concept that the customer is always right no longer universally applies. Moreover, Guilbault provides adequate criticality of her own argument and considers many opposing views such as Nguyen and Rosetti's (2013) claim that there is an ideological gap when students are considered consumers. This is the disntinction between what a student wants and what is in their best interests according to the academic. However, Guilbault (2018) rebuts these arguments due to lack of empirical evidence and claims that it is the definition of what a customer is that is causing the problem. Despite this, she does not have any evidence to support such claims.

Although most of the studies mentioned have demonstrated that students reject the consumer identity (Williams, 2013; Saunders, 2014; Tomlinson, 2017), there is a general consensus that through the implementation of government policy and public scrutiny students are in fact labelled as consumers. However, it must be noted that contemporary research (Bunce, 2017) highlights a potential increase in the number of students adopting a consumer identity. This finding is also corroborated by Matthews (2018), although her research has focused on the marketisation of higher education institutions in Australia.

\section{The Effects of the Student-Consumer Mindset}

Many academics acknowledge a range of negative effects which stem from the existence of the student-consumer mind-set (Sharrock, 2000; Brule, 2004; George, 2007; Titus, 2008; Lesnik-Oberstein, 2015; Bunce, 2017; Matthews, 2018). Fewer denote positive effects (Maguad, 2007; Guilbault, 2018). LesnikOberstein (2015) is an active academic in the UK, specialising in areas such as 
children's literature and culture and as such, holds strong views regarding the student-consumer mind-set. She claims that classifying students as consumers undermines and degrades university attributes such as creativity, social justice and critical thought. As a result, she argues that such notions are being replaced with marketised demands, and pressures to standardise, conform and obey and are degrading the ethos of higher education. Lesnik-Oberstein (2015) also notes that such micro-management practices are eroding academics' ability to teach and research effectively. She posits that academics are suffering from unprecedented levels of anxiety as a result of their performance being measured by consumer satisfaction scores. However, her claims are based on personal experience rather than empirical evidence. This anxiety may also pervade teaching practices, resulting in academics conducting their sessions in way that appeases students rather than pushing them out of their comfort zone (Brule, 2004; Titus, 2008; Matthews, 2018). Other academics have voiced concerns over education being redefined by a simple exchange rather than a creative process (Sharrock, 2000) and the prioritisation of mark percentages over learning (George, 2007).

Matthews (2018) claims that treating students like consumers affects teaching. Particularly she notes that pushing students out of their comfort zones, providing critical feedback and challenging their thinking are substituted for fear of receiving bad feedback evaluations. Furthermore, Matthews (2018) claims that students possessing the consumerist view of themselves consequently underperform, as they shift the responsibility of their learning onto the lecturers. This correlation between lower academic achievement and a consumer mind-set was also confirmed in Bunce's (2017) study. Although Matthews' work focused on Australian universities, her work has attracted many awards and has been found to be generalisable to universities in the UK due to 
their inherent similarities (Marginson, 2014; Coaldrake, 2016). Similarly, many academics have noted that rigorous lecturers are under pressure to dumb-down their content in order to attract higher customer satisfaction scores (Driscoll and Wicks, 1998; Emery et al., 2001; Bunce, 2017). This shows that although customer satisfaction scores may be higher, this increase may not be attributable to a higher standard of teaching. In fact, this posits that student consumers are looking for high grades with minimal effort and responsibility (Bishop, 2016; Bunce, 2017). Matthews (2018) also offers a counter-narrative to that of students-as-consumers and claims that students are better conceptualised as partners. She adds that stimulating dialogue between students and lecturers and embracing students as partners demonstrates many benefits such as enhanced trust, student engagement, self-efficacy and metacognitive learning (ITALI, 2018).

The National Student Survey (NSS) is responsible for measuring student satisfaction, but at the same time it ranks and audits the quality of teaching provided by institutions. The results are subsequently used by the HEFCE and QAA to hold universities to account for the quality of the experience they provide for their students (UCU, 2010). Bishop (2016), a professor at Oxford University and executive member of the Campaign for the Defence of British Universities, argues that NSS data is not indicative of teaching quality as student satisfaction scores are higher when students are awarded high marks and given less-challenging assessments. Furthermore, the UCU (2010) claims that in foresight of student satisfaction scores, some institutions may modify courses to make them more customer-friendly. They argue that this conflicts with providing a quality and challenging education and ultimately undermines the professionalism and expertise of the lecturers, which underpin the validity of a worthwhile education (UCU, 2010). 
Lomas (2007) conducted research into the perceptions of academic staff about student-consumerism. Although she did not specifically detail the effects of consumerism on teaching practices, she did research the disadvantages. Lomas interviewed six members of academic staff from different disciplines, three from a pre-1992 university and three from post-1992 institutions. She found that academics perceived a shift towards an entitlement culture in higher education (Morely, 2003) and that academic rigour has been substituted for spoonfeeding, as this ensures courses recruit well and bring in revenue. However, she found that the perceptions of academic staff differed depending on their discipline, which is also examined in this study. Some lecturers, such as those from nursing who are more care-orientated, were more positive when detailing the student-as-consumer approach. Lomas also found that newer universities are more customer-orientated than older, traditional universities. However, Lomas' (2007) data may lack generalisability due to the small sample size used in the study and as the tuition-fee increases came into force in 2012, a more contemporary study is needed.

\section{Complaints and a higher-level of entitlement}

A notable characteristic of a consumer-oriented environment is the customer entitlement to complain should a product or service be defective or unfit for purpose. Concurrent to this, the Office of the Independent Adjudicator (OIA) has reported higher numbers of complaints from students (Lomas, 2007; Garner, 2009; OIA, 2017). The number of student complaints reported by the OIA reached its peak in 2014 at a total of 2,040, however the latest statistics for the year of 2017 shows that the total number of complaints has dropped to 1,635. This timeline is consistent with the tuition fee increases in England and Wales. Adams (2018) claims that student complaints in the year of 2017 rose $8 \%$ from 
the previous year and more than $£ 650,000$ was paid out to unsatisfied students. Furthermore, it is reported that most complaints were about 'academic status' which refers to exam marks and degree results (OIA, 2017). This synthesises Bunce's (2017) claim that students view obtaining a degree as a financial transaction and something that can be bought, rather than something which is earned by the student. This also illustrates a shift in responsibility for student achievement, from the learner to the lecturer (Bunce, 2017) and points towards a culture of entitlement (Morely, 2003).

Furedi (2015) claims that the complaints culture has created a defensive approach to education, attempting to reduce disputes and litigation with students. Further to this, he claims that courses are being made more customerfriendly rather than being academically rigorous. Furedi (2015) concludes that as a result of marketisation, the customer is always right ethos has permeated universities. He claims that this assimilates that students know how they want to be taught and therefore academics are reduced to service providers rather than autonomous experts. This consequently discourages academics to use the expertise that they have been appointed for and lessens the value of their expert judgement when providing feedback and discussing disputed grades (ibid). However, Furedi (2015) takes a philosophical approach and bases his assumptions on previous sociological research and theory, rather than empirical data. 


\section{Part III: Method}

A review of the literature identified a gap in existing research, as ample evidence on the need for an academic-staff focused approach was discovered (Lomas, 2007; Saunders, 2014; Bunce 2017; Matthews, 2018). Much research has been student-focused, whereas this research proposes to provide an alternative perspective. This area of exploration seeks to discover the effects of studentconsumerism on discipline-specific teaching practices from the perspective of academic staff. The research opted to collect empirical data due to the little academic discourse available on the effects of the student-consumer mind-set from the perspective of academic staff. To address this gap, I adopted a case study research design which examined the student-consumer concept and its effects on teaching and associated practices in a post-1992 institution. A post1992 university was chosen as part of this study due to newer institutions reportedly presenting a higher level of student-consumerism (Lomas, 2007; Molesworth et al., 2010; Jabbar et al. 2018). Although some may express concerns about the generalisability of examining a single study in one institution, it may be counter-argued that if a case study is similar to others of its type then generalisability can be achieved (Denscombe, 1998). Moreover, greater importance is attributed to the relatability of a study (Bassey, 1998). However, it is important to note that this study does not seek to make broad generalisations.

Within the case study, I conducted eight in-depth interviews with academic members of staff split evenly across two different departments; education and law. Academic staff were selected from two pre-determined disciplines, law and education. These disciplines were chosen due to the researcher studying education and working within law, therefore data sources were easily accessible 
within the time constraints of this research. The research was conducted in partial fulfilment of the researcher's master's degree in education and as such, the project was time-constrained to a period of approximately three months. Therefore, as it was not possible to interview participants from each discipline due to time constraints and accessibility issues, law and education were selected as they are at opposite ends of the spectrum in terms of graduate salary. It has been reported that the study of law offers the best graduate pay progression, whereas education offers less than half of the scope of pay progression than that of law (Telegraph, 2018). Therefore, it was the researcher's aim to balance any potential intrinsic bias stemming from the earning potential of field-specific graduate salaries.

A convenience sampling technique was adopted to target the academic interview participants in the first instance. Convenience sampling is where the researcher draws information from a group or subpopulation that is easily accessible, geographically proximate, available and willing to volunteer (Kemper et al., 2003; Etikan et al., 2016). Therefore, it is a popular purposive strategy adopted by academics (Kemper et al., 2003). Although, it is not without its limitations, as some academics claim that it is likely to be biased (Miles and Huberman, 1994) as it is a form of non-probability sampling. Furthermore, a snowballing approach, using informants to identify potential participants to include in the study (Kemper et al., 2003), was also used to access potential participants. This approach was fulfilled through the distribution of an open invitation through email, which was circulated only to staff who teach in the departments of education and law. The invitation to participate was then further dispersed by professional acquaintances and those within the researcher's network. The potential participants then self-selected themselves to take part 
in the interviews. This again attracted interview participants via a process of selfselection.

The relatively small sample size enabled the researcher more time to drill deeper into the academics' personal thoughts, feelings and experiences and to draw out the effects that the concept of students as consumers had on their academic practices. The interview questions were semi-structured in order to provide clear guidance on the area to be discussed, but open so as not to limit the interviewee should they wish to expand on their response. Open questions were also used in order to elicit descriptive and meaningful narratives about lived experiences (such as 'tell me your thoughts on the concept that students are consumers of their university education?'). The interviews covered a range of themes within the ambit of the effects of student consumerism on how the academic delivers their teaching and learning. Examples of areas covered during questioning are; how consumerism has affected teaching practices, classroom management strategies, interaction with students, the provision of feedback, anxiety about student satisfaction scores and the quantification of value for money. The seniority of the role of each participant was not specified and a range of teaching-intensive roles were invited to participate, to provide breadth and depth across all roles and enrich the potential variation of data.

\section{Limitations of the Study}

There are some notable limitations of the study that must be considered to inform further research into this area. The researcher acknowledges the difficulties associated with small sample sizes in achieving generalisability. Although some may express concerns about the generalisability of examining a 
single study in one institution, it may be counter-argued that if a case study is similar to others of its type then generalisability can be achieved (Denscombe, 1998). Moreover, greater importance is attributed to the relatability of a study (Bassey, 1998). However, it is important to note that this study does not seek to make broad generalisations.

\section{Managing ethical issues}

The British Educational Research Association (BERA) provides distinct ethical guidelines for conducting educational research (BERA, 2018) which the researcher adhered to throughout. Furthermore, ethical approval was sought from the researcher's institution. The researcher worked as an embedded researcher, meaning that the research was undertaken within the researcher's own place of work. Potential issues of privacy and power influence over the participants were considered, however the researcher used unobtrusive strategies of distribution to combat the effects of familiarity. Such strategies were to distribute interview invitations via email and social media channels, rather than face-to-face. Cohen et al., (2017) claim that boundaries must be maintained within instances of embedded interpretive research, however they acknowledge that problems of influence and other associated humanistic problems may be inescapable. In fact, some academics argue that there are benefits associated with being an embedded researcher, such being immersed in the host organisation (Lewis and Russell, 2011; Marshall et al., 2014). This arguably enhances understanding of the pressures faced by the organisation and helps to tailor recommendations accordingly (Marshall et al., 2014; McGinty and Salokangas, 2014). 
Informed consent was obtained through the creation and distribution of a participant information sheet and a consent form. The information sheet provided detailed information about what data would be collected, the purpose of the research and how the data would be used. The consent form was distributed to each participant, together with the initial interview invitation which was signed immediately prior to commencement of the interview.

The interviews were recorded using a voice-recording and transcription software application on the researcher's mobile device called Otter. This enabled the researcher to more efficiently transcribe the qualitative data and to identify codes more easily. All transcripts were downloaded onto the researcher's computer within twenty-four hours of recording and were inputted into a password-encrypted folder. The transcripts were then anonymised, and any personal information remained confidential throughout. Although, complete confidentiality could not be maintained in the name of research, as there is a duty on the researcher to present the findings (Wiles et al., 2006). However, in research terms confidentiality is often referred to as privacy (Oliver, 2003; Gregory, 2003) and anonymisation of data. Moreover, the researcher endeavoured to ensure that, so far as possible, the participants were anonymised and unidentifiable in the final report.

\section{Approach to Data Analysis}

The researcher adopted a general inductive approach to analysing the qualitative data, which is common among qualitative researchers (Dey, 1993; Bryman and Burgess, 1994; Thomas, 2006). Therefore, the researcher immersed herself in the data to allow themes to emerge of their own accord (Kondracki 
and Wellman, 2002), also described as inductive category development (Mayring, 2000). Further to this, a manual coding technique was used to analyse the qualitative data. However, the Otter software helped with the coding process initially, as it extracted frequently used words and phrases from the data and created tag-lines.

\section{Part IV: Discussion}

This section presents the data extrapolated from the qualitative interviews with academic staff members and provides a discussion of these findings in connection with the existing literature and the gaps therein. It does this by key theme, these are; tuition fee increases as creators of consumerism, consumerism as a catalyst for change, value for money, a culture of appeasement and a defensive approach to education. The five key themes selected and discussed below were the most prevalent and important themes to arise from the data in relation to the research question identified. Other themes did emerge but lie outside of the scope of this paper. The discussion provides direct quotations from the interviews as evidence of the qualitative analysis conducted. The researcher notes that many of themes highlighted do not operate in isolation, therefore some data is discussed in reference to more than one theme.

\section{Tuition Fees Increases as Creators of Consumerism}

One of the key themes to emerge from the qualitative data was that the introduction and subsequent increases in student tuition fees led to the 
consumerist nature of higher education. This argument was articulated by all participants and there was consensus among academics from education and law in this respect. Example responses are listed below.

Interviewee 2: "It does go straight back to just major sort of fees. Even if you're very careful of your money, you're going to be 27,000 in debt from day one."

Interviewee 8: "There is an emerging ethos amongst students that they see themselves as consumers, evidenced by some of the comments that we get like oh, but I pay $£ 9000$ a year for this..."

There was an apparent consensus among the respondents that the rise of the student-consumer mind-set was largely associated with tuition fee increases. Some of the respondents also stated that their students had commented on the fact that they are paying nine-thousand pounds a year. This imposes greater accountability on academics to deliver a service that matches the students' financial contribution, reinforcing the views of Bunce (2017). Interviewee five claimed that treating students as consumers is dangerous and that it encourages surface learning, rather than a deeper engagement and a love of learning itself.

The participants confirmed the general views of Molesworth et al. (2011), agreeing that the student-as-consumer concept has been embraced on a foundation of marketisation. Specifically, they unanimously attributed the rise in consumerism to the rise in student-funded tuition fees, confirming the views of Farrell and Tapper (1992) Brown and Carasso (2013), McGettigan (2013) and Palfraymen and Tapper (2014; 2016). Some participants had also experienced similar complaints to those identified by Bunce (2017), implying that paying nine-thousand pounds a year justified a higher standard of service. This suggests that students seek greater value for money from their university in return for 
their substantial contribution, as would be expected in the private sector (Woodall et al., 2014).

\section{Consumerism as a Catalyst for Change}

This theme arose as a result of the participants being asked how and to what extent their job roles and teaching practices had been affected by the studentconsumer mindset.

Interviewee 4: "I don't think it's changed how I teach, deliver or respond to students."

Interviewee 5: "I've been sort of pressured maybe to give them what they want, as opposed to maybe what we think will be more useful for them."

The qualitative data on consumerism as a catalyst for change varied across the departments significantly. Some interviewees stated that their job role had not changed at all due to the rise of consumerism. Whereas others alluded to a power shift from staff to student and a greater responsibility on the part of the lecturers to ensure that all content is taught, rather than students being taught how to be independent learners. It was often the interviewees from the education department who did not see a change in their job role, however all of those in law did. This may be due to the education academics being accustomed to adhering to regulatory bodies such as OFSTED, and therefore less autonomy in their role is common practice. Whereas the same regulations are not common practice within the law department. 
All participants from the education department felt that their teaching practices had not been affected by student consumerism. The main reason given for this was that those in the education department often trained teachers and so their teaching practices had to emulate the standard expected of their students in their future careers.

Interviewee 1: "I'm really passionate about what I teach and believe in good teaching, good research, etc. So, I would want to deliver quality whether they see themselves as a learner, consumer, or whatever."

Interviewees from the education department often referred to consumeroriented teaching as good teaching. This contrasted the perspective of many in the law department who referred to consumer-oriented teaching practices negatively. However, interviewees across both sectors referred to having to become more defensive in their teaching strategies and more careful to ensure that the content meets the expectations. One law academic referred to the way in which teaching must meet the needs of a tutor-dependent student because of the rise of consumerism, and that it has affected independent study requirements.

The qualitative data on this theme illustrated a contrast between the views of those in the education department and those in law. The law lecturers' responses mirrored the claims of Brule (2004), Titus (2008) and Matthews (2018), that consumerism results in academics conducting their sessions in way that appeases students rather than pushing them out of their comfort zone. Furthermore, they agreed with the claims of Driscoll and Wicks (1998), Emery et al. (2001) and Bunce (2017) that academics are under-pressure to dumb-down content in order to appease their students, thus improving student satisfaction 
scores. This would suggest that treating students as consumers is depleting the quality of higher education and ameliorating traditional educational values (Bunce, 2017). However, there does not appear to be a consensus among the different disciplines.

As the education lecturers associated consumer-driven teaching with highquality teaching, their remarks align with the views of Guilbault (2018) who acknowledges the value in student consumerism. Therefore, for some academics, consumerism may set a high-standard for teaching practices and be associated with good teaching. Although, the findings indicate that consumerdriven teaching methods may be suitable for some disciplines, but not for others.

\section{Value for Money}

Value for money was a key theme to emerge from the interview data. There was considerable variation within the data about value for money, which suggests that it is largely subjective. However, for the most part, the interviewees claimed that value for money is represented by quality, innovative and engaging teaching and learning.

Interviewee 3: "They need to have decent quality teaching. Maybe it is those staff that do go above and beyond a little bit."

Interviewee 6: "Academics who are very teaching focused and use digital technology, provide lots of feedback and engaging workshops."

This representation seems to match how students quantify value for money, reiterating the claims of Coughlan (2017) that teaching quality is a factor which influences whether students believe they are receiving value for money or not. 
However, the researcher acknowledges that what consists of quality teaching may be constructed differently, depending on perception.

Caplan's (2018) association between value for money and the attainment of desirable employment was also validated in the interview data, as one interviewee claimed value for money lies within graduate employability. Interestingly, one interviewee claimed that students achieving value for money is dependent on whether they achieve a good degree. This maps to Bunce's (2017) hypothesis that students seek to obtain a degree and a high classification of degree, rather than becoming cultured, independent, critically thinking subject experts. Even though, the acquirement of such skills would be much more valuable to future employees than grade classification. Moreover, Bevan's (2018) view that league tables are ineffective indicators of value for money is confirmed within this study, as none of the staff participants associated league tables with value for money. However, students may value league table positions more so than academic staff.

Heightened pressure to be available for students more often, face-to-face and via email was also commonly noted throughout the interviews. This included responding to queries outside of office hours and when on annual leave.

Interviewee 5: "I probably won't be the only lecture that feels that you have to be there for your students all of the time, there are pressures to respond immediately to make sure that the student is seen as soon as possible."

This relates to the debate regarding value for money, as it is increasingly an element which students expect more from in consideration of their financial investment (Money et al., 2018). Student-tutor contact hours are an important part of a student's university education. However, the increasing expectation to 
dedicate more time, and time which is outside of office hours, may dilute time dedicated to other activity. For example, academics need to have time to develop research and are entitled to their own personal free time outside of office hours, just as much as any other profession.

Overall, the data suggest that value for money for students in a higher education context is difficult to pinpoint as it is largely subjective. However, a collection of themes has been associated with optimising value for money. Such areas are quality and innovative teaching, effective use of resources, an emphasis on graduate employability, detailed feedback, sufficient student-tutor contact hours, taking into consideration the needs of both staff and students, and obtaining a good degree. Therefore, a holistic approach to providing value for money is suggested.

\section{A Culture of Appeasement}

Commonly noted throughout the interviews with academics was the notion that traditional academic values had been ameliorated in favour of student appeasement. However, this view was more widely held by academics in the discipline of law than in education. A key argument was that student satisfaction scores had a role in creating the shift to a consumer-oriented teaching approach.

All the interviewees agreed that they take student satisfaction scores into account and most participants detailed this as a positive aspect, which largely contradicts the literature discussed (UCU, 2010; Furedi, 2015). Although interviewee eight, a law academic, commented that emphasis is put onto making content more fun and appealing rather than intellectually challenging, to optimise student satisfaction scores. Interviewee four from the education department noted that student satisfaction was certainly something that was 
considered, however that it is not about the scores but producing outstanding future teachers.

The issue of substituting academic rigour in favour of a student-centred approach, which produces higher student satisfaction scores, is well documented in the literature by the UCU (2010). They claim that modifying modules to become more customer-friendly is common practice in todays commercialised higher education market. This may undermine lecturers' professionalism and expertise which is at the heart of a worthwhile education (UCU, 2010). The empirical research substantiated the view that treating students as consumers does not encourage deep engagement with the subject and a love of learning (Molesworth et al., 2009; Williams, 2010; Woodall et al., 2014). In fact it is promoting a culture where students simply seek to obtain a degree, rather than becoming lifelong learners or subject experts (ibid). Interviewee five commented that this is not in the best interests of the students, which links to Nguyen and Rosetti's (2013) claim that there is an ideological gap when students are considered consumers. This suggests that there is distinction between what a student wants and what is in their best interests according to the academic. However, there appears to be less need for change in the education department.

Across both disciplines, but more so in the law department, studentconsumerism is seemingly limiting academic discretion and judgement, in favour of student appeasement and retention. This raises questions about the autonomy of academics and may undermine the value of their professionalism, as well as impacting the quality of their teaching. However, although it is not made clear in the literature, it is possible that academically rigorous activities can also be made fun and engaging. The findings show that the university needs 
to find a happy balance between providing a quality service to the student consumer, whilst still encouraging a culture of lifelong learning, critical thinking and deeper engagement with the subject.

\section{A Defensive Approach to Education}

The use of defence strategies was a recurring theme within the interview data, and a key consideration when the participants were asked about changes to their classroom management strategies as a result of the student-as-consumer mindset. This maps to Furedi's (2015) claim that the complaints culture has created a defensive approach to education, attempting to reduce disputes and litigation with students. One interviewee from law insisted that students are not disciplined in the correct manner and are treated with a light touch because of consumerism. The interviewee also alluded to an air of trepidation when disciplining students, to retain their financial investment.

Interviewee 6: "Extreme behaviour is not so much accepted, but students expressing this behaviour are not shown the door and are managed and coaxed into compliance to keep and retain the $\mathrm{f9000}$ a year."

This echoes Bunce's (2017) claim that educational values are deteriorating in favour of retaining students' financial investment. However, the researcher notes that this was an isolated opinion within the sample.

One education academic deemed defence strategies necessary, in terms of having an audit trail, should complaints arise. A defensive approach was also detailed by another interviewee from the law department, who opined that previous student satisfaction scores have prompted planning to minimise the 
potential for complaints. Therefore, this is a common theme across both departments and does not seem to be isolated to the discipline of law.

Interviewee 7: "I've done things slightly differently this year, in terms of trying to ensure that there is minimum potential for a complaint to be made."

Student satisfaction scores were noted as a key catalyst of the defensive approach, by those who experienced this shift in approach. All interviewees agreed that they take student satisfaction scores into account and most participants detailed this as a positive aspect, which largely contradicts the literature discussed (UCU, 2010; Furedi, 2015; Lesnik-Oberstein, 2015). However, issues were raised about substituting traditional academic rigour for fun and appealing sessions, as previously mentioned, and the fear of poorscoring creating a defensive, adversarial environment (Furedi, 2015).

The value of student satisfaction surveys has been noted. It is apparent that these are a useful tool for interpreting the student voice and making positive improvements to courses. It appears that the issues lie within the scoring system attached to the student satisfaction surveys, which may be causing unprecedented levels of anxiety over the numerical measurement of performance (Lesnik-Oberstein, 2015). This in turn may be a factor that is contributing to the existence of a defensive approach to education. Inevitably, this may affect the quality of the education provided and so needs to be rectified. 


\section{Part V: Conclusion and Recommendations}

\section{Conclusion}

This paper has explored the effects that the student-consumer mindset has on teaching and associated practices within a post-1992 university. This area of exploration was investigated through a qualitative analysis, based on the perceptions of academic staff. It found that common negative effects associated with the rise of consumerism were; a defensive approach to education, heightened student expectations in relation to value for money and appeasement of students, in substitution for academic rigour. However, the data also indicated that student-consumerism may be a catalyst for positive change in some circumstances. Also commonly noted throughout the study were the varying opinions and approaches detailed by the two academic disciplines involved. The academics within the department of education were more likely to perceive student-consumerism positively than the academics interviewed in the law department. The research suggests that this may be due to the lack of regulation in legal education, as opposed to the education sector, which is heavily regulated by bodies such as OFSTED. This indicates that the education academics are more accustomed to providing a student-centred and consumer driven service. Alternatively, the disparity between disciplines may be

driven by the differences between the type of students who choose to study education, and those who choose to study law. The future earning capacity of law graduates is much greater than that of education graduates and therefore law students may be inherently more consumerist and driven by financial incentives, whereas education students may decide to study because it is their vocation. On this basis, this paper highlights several practical recommendations and suggestions for future research in this institution. 


\section{Recommendations}

Student satisfaction scores were linked to members of academic staff fostering a defensive approach to teaching, which may impact teaching quality. This paper recommends that tutors embed reference to the categories assessed by student satisfaction surveys into their sessions, to mitigate any incomplete understandings that students may have when completing them. Ensuring that the student satisfaction questions are clearly addressed in the sessions will enhance the qualitative feedback of students, and reduce staff anxiety in this area. However, more empirical research is needed on the extent to which student satisfaction scores affect academic staff members' ability to perform their roles, which lies outside of the scope of this paper. This question warrants an in-depth, qualitative study of the impact of student satisfaction accountability on academic staff members' experience of teaching in HE.

An important concern to emerge from the study was that some academics felt that they had to "dumb-down" content in order to appease students, although this concern was largely held by staff from the law school. The researcher recommends that further research is undertaken into how students quantify value for money in a higher education context. Specifically, how to make sessions fun and stimulating, without lacking academic rigour must be explored further. Although, it is clear that a holistic approach to ensuring value for money is needed, encompassing quality and innovative teaching, graduate employability, optimal use of resources and helping students to obtain the best degree classification. Value for money was an area that many of the academic participants noted would be best measured by students. Therefore, due to the topical nature of quantifying value for money in an education context (Parliament, 2018), this institution would benefit from further comparative 
research between staff and students views on value for money, via an in-depth, qualitative study.

Finally, this paper recommends that further interdisciplinary research into the effects of consumerism on teaching practices is conducted, as the current study highlighted some interesting differences between the two departments. An institutional, longitudinal study should be conducted in order to unearth further disparities between disciplines. Furthermore, this research could be replicated at a national level to inform wider HE policy.

\section{Reference List}

Adams, R. (2018). Student complaints about UK universities growing says watchdog. [online]. The Guardian. [Viewed 27 ${ }^{\text {th }}$ March 2019]. Available from: https://www.theguardian.com/education/2018/apr/26/student-complaintsabout-uk-universities-growing-says-watchdog

Alford, J. (2002). Defining the client in the public sector: A social exchange perspective. Public Administration Review, 62(3), 337-346.

Amis, K. (1960). Lone Voices: Views of the Fifties. Encounter. 15(82), 8.

Angulo, A.J. (2016). Don't turn students into consumers - the US proves it's a recipe for disaster. [online]. The Guardian. [Viewed $27^{\text {th }}$ March 2019]. Available from: https://www.theguardian.com/higher-educationnetwork/2016/jul/06/dont-turn-students-into-consumers-the-us-proves-its-arecipe-for-disaster 
Ashton, D. N. and Green, F. (1996). Education, Training and the Global Economy. Cheltenham, UK: E. Elgar.

Bassey, M. (1998) Case Study Research in Educational Settings. Buckingham: Open University Press.

Bathmaker, A.M. (2003). The expansion of higher education: A consideration of control, funding and quality. In Bartlett, S. and Burton, D., eds. (2003). Education Studies: Essential Issues. London: Sage, 169-189.

Bedoyere, R. (2018). Which UK universities offer the most value for money? [online]. The Complete University Guide. [Viewed 23 ${ }^{\text {rd }}$ May 2018] . Available from: https://www.thecompleteuniversityguide.co.uk/news/which-ukuniversities-offer-the-most-value-for-money/

BERA. (2018). Ethical Guidelines for Educational Research, $4^{\text {th }}$ Ed. [online].

BERA. [Viewed $6^{\text {th }}$ July 2018]. Available from: https://www.bera.ac.uk/wpcontent/uploads/2018/06/BERA-Ethical-Guidelines-for-Educational-

Research_4thEdn_2018.pdf?noredirect=1

Bevan, N. (2018). League tables should be relegated. [online]. Times Higher Education. [Viewed 27 $7^{\text {th }}$ March 2019]. Available from: https://www.timeshighereducation.com/opinion/university-league-tablesshould-be-relegated

Bishop, D (2016). NSS and teaching excellence: the wrong measure, wrongly analysed. [online]. Times Higher Education. [Viewed 27 th March 2019]. Available 
from: $\quad$ https://www.timeshighereducation.com/blog/nss-and-teachingexcellence-wrong-measure-wrongly-analysed

Boxall, M. (2018). Debunking the value for money myth in higher education. [online]. Times Higher Education. [Viewed 27 $7^{\text {th }}$ March 2019]. Available from: https://www.timeshighereducation.com/blog/debunking-value-money-mythhigher-education

Brown, P. and Lauder, H. (1995) Post-Fordist Possibilities: Education, Training and National Development IN Bash, L and Green, A. (eds) Youth, Education and Work. World Yearbook of Education 1995, London: Kogan Page, p.19-32.

Brown, R. (2015). The marketisation of higher education: issues and ironies. University of West London. [Viewed 27 $7^{\text {th }}$ March 2018]. Available from: https://www.uwl.ac.uk/sites/default/files/Departments/Research/new_vistas/ vol1_iss1/vol1_iss1_art1_23April2015.pdf

Brown, R. and Carasso, H. (2013). Everything for Sale? The marketisation of UK higher education. Abingdon: Society for Research into Higher Education and Routledge.

Brule, E. (2004). Going to market: Neoliberalism and the social construction of the university student as an autonomous consumer. In M. Reimer (Ed.), Inside the corporate U: Women in the academy speak out (pp. 255-281). Toronto: Sumach Press.

Bryman, A. (2008). Of methods and methodology. Qualitative Research in Organizations and Management: An International Journal. 3(2) 159-168. 
Bryman, A. (2016). Social Research Methods. $5^{\text {th }}$ Ed. Oxford: Oxford University Press.

Bryman, A., \& Burgess, R. G. (Eds.). (1994). Analyzing qualitative data. London: Routledge.

Bunce, L. (2017). The student-as-consumer approach in higher education and its effects on academic performance. Studies in Higher Education. 42(11) 19581978.

Caplan, B. (2018). Higher education: what is it good for? [online]. Times Higher Education. [Viewed 27 ${ }^{\text {th }}$ March 2019]. Available from: https://www.timeshighereducation.com/features/higher-education-what-itgood

Coaldrake, P. (2016). Deregulation and marketization in English Higher Education - lessons from Australia [online]. Policy Exchange. [Viewed 27 $7^{\text {th }}$ March 2019]. Available from: https://policyexchange.org.uk/event/deregulation-andmarketisation-in-english-higher-education-lessons-from-australia/

Cohen, L., Manion, L. and Morrison, K. (2017). Research Methods in Education. $8^{\text {th }}$ ed. London: Routlegde.

Coughlan, S. (2017). Students say university value for money falling. [online]. $B B C$ News. [Viewed 27 $7^{\text {th }}$ March 2019]. Available from: https://www.bbc.co.uk/news/education-40187297 
Dearing, R. (1997). Higher Education in the Learning Society: Report of the National Committee of Inquiry into Higher Education. London: Her Majesty's Stationary Office.

Denscombe, M. (1998). The Good Research Guide for Small-scale Social Research Projects. Buckingham: Open University Press.

Dey, I. (1993). Qualitative data analysis: A user-friendly guide for social scientists. London: Routledge.

Driscoll, C. \& Wicks, D. (1998). The customer-driven approach in business education: A possible danger? Journal of Education for Business, 74, 58-61.

Education Committee. (2017). Value for money in higher education: Committee lunches inquiry. [online]. Parliament. [Viewed 27 th March 2019]. Available from: https://www.parliament.uk/business/committees/committees-a-z/commonsselect/education-committee/news-parliament-2017/value-for-money-highereducation-launch-17-19/

Emery, C. R., Kramer, T. R. and Tian, R. G. (2001). Return to academic standards: a critique of student evaluations of teaching effectiveness. Quality Assurance in Education. 11(1) 37-46.

Etikan, I., Musa, S. A. and Alkassim, R. S. (2016). Comparison of Convenience Sampling and Purposive Sampling. American Journal of Theoretical and Applied Statistics. 5(1) 1-4.

Farrell, S. and Tapper, E. (1992) Student loans: The failure to consolidate an emerging political consensus. Higher Education Quarterly, 46 (3), 269-85. 
Furedi, F. (2015). Introduction to the marketisation of higher education and the student as consumer. In The Marketisation of Higher Education and the Student as Consumer by (ed.s) Molesworth, M, Scullion, R and Nixon, E. Routledge: London.

Garner, R. (2009). The Big Question: why are students complaining so much, and do they have a case? [online]. The Independent. [Viewed 27 $7^{\text {th }}$ March 2019]. Available from: https://www.independent.co.uk/news/education/educationnews/the-big-question-why-are-students-complaining-so-much-and-do-theyhave-a-case-1687677.html

George, D. (2007). Market overreach: The student as customer. The Journal of Socio-Economics, 36, 965-977.

Gosden, P. (1983). The Education System since 1944. Oxford: Robertson.

Gregory, I. (2003). Ethics in Research. London: Continuum.

Guilbault, M. (2018). Students as customers in higher education: The (controversial) debate needs to end. Journal of Retailing and Consumer Services. 40, 295-298.

Higher Education and Research Act 2017.

Hom, W.(2002). Applying customer satisfaction theory to community college planning of student services. [online]. IJournal, 2. [Viewed 24 ${ }^{\text {th }}$ June 2018]. Available from: http://www.ijournal.us/issue_02/ij_issue02_WillardHom_01.Htm 
Jabbar, A, Analoui, Bejan, Kong, K and Mirza, M. (2018). Consumerisation in UK higher education business schools: higher fees, greater stress and debatable outcomes. Higher Education. 76(1) 85-100.

Johnstone, D. B., and Marcucci, P. N. (2010). Financing Higher Education Worldwide: Who Pays? Who Should Pay? Baltimore: JHU Press.

Kemper, E. A., Stringfield, S., \& Teddlie, C. (2003). Mixed methods sampling strategies in social science research. In A. Tashakkori \& C. Teddlie (Eds.), Handbook of mixed methods in the social and behavioral sciences (pp. 273-296). Thousand Oaks, CA: Sage.

Kondracki, N. L., and Wellman, N, S. (2002). Content analysis: review of methods and their applications in nutrition education. Journal of Nutrition, Education and Behavior. 34(4):224-30.

Lesnik-Oberstein, K. (2015). Let UK Universities do what they do Best - Teaching and Research. [online]. The Guardian Letters. [Viewed $27^{\text {th }}$ March 2019]. Available from: https://www.theguardian.com/education/2015/jul/06/let-ukuniversities-do-what-they-do-best-teaching-and-research

Lewis, S. J. and Russell, A. J. (2011) Being embedded: Away forward for ethnographic research. Ethnography 12, 398-416.

Lomas, L. (2007). Are Students Consumers? Perceptions of Academic Staff. Quality in Higher Education. 13(1) 31-44. 
Lord Browne. (2010). Securing a Sustainable Future for Higher Education: An Independent Review of Higher Education Funding and Student Finance. [online]. Gov.uk. [Viewed 27 ${ }^{\text {th }}$ March 2019]. Available from: https://assets.publishing.service.gov.uk/government/uploads/system/uploads /attachment_data/file/422565/bis-10-1208-securing-sustainable-highereducation-browne-report.pdf

Maguad, B. (2007). Identifying the needs of customers in higher education. Education. 127(3) 332-343.

Marginson, S. (2014). Links with China: why Australian universities are leading the way. [online]. The Guardian. [Viewed 27 $7^{\text {th }}$ March 2019] https://www.theguardian.com/higher-educationnetwork/blog/2014/jul/07/australian-uk-universities-links-china

Marshall, M. Pagel, C. and French, C. (2014). Moving improvement research closer to practice: the Researcher-in-Residence model. BMJ Qual Saf 23, 8015.

Matthews, K. (2018). Stop treating students like customers and start working with them as partners in learning. [online]. The Conversation. [Viewed $27^{\text {th }}$ March 2019]. Available from: http://theconversation.com/stop-treatingstudents-like-customers-and-start-working-with-them-as-partners-in-learning93276

Mayring, P. (2000). Qualitative content analysis. [online]. Qualitative Social Research 1(2). [Viewed $10^{\text {th }}$ July 2018]. Available from: http://www.qualitativeresearch.net/fqs-texte/2-00/02-00mayring-e.htm 
McGettigan, A. (2013). The Great University Gamble: Money, markets and the future of higher education. London: Pluto Press.

McGinity, R and Salokangas, M. (2014). Introduction: "Embedded Research" as an approach into academia for emerging researchers. Manag Educ. 28:3-5.

McRae, A. (2018). What does value for money men for English higher education? [online]. Times Higher Education. [Viewed 27 ${ }^{\text {th }}$ March 2019]. Available from: https://www.timeshighereducation.com/features/what-does-value-moneymean-english-higher-education

Miles, M. B., Huberman, M. A., and Saldaña, J. (2014). Qualitative Data Analysis a Methods Sourcebook [online]. Research Talk. [Viewed $6^{\text {th }}$ June 2018].

Available from: http://researchtalk.com/wp-content/uploads/2014/01/MilesHuberman-Saldana-Drawing-and-Verifying-Conclusionberas.pdf

Miller, B. (2010). Skills for sale: What is being commodified in higher education? Journal of Further and Higher Education. 34(2), 199-206.

Molesworth, M, Nixon, E and Scullion, R. (2009). Having, being and higher education: the marketisation of the university and the transformation of the student into consumer. Teaching in Higher Education. 14(3) 277-287.

Molesworth, M, Scullion, R and Nixon, E. (2010). The Marketisation of Higher Education and the Student as Consumer. London: Routledge.

Money, J., Nixon, S., Tracy, F., Hennessy, C., Ball, E and Dinning, T. (2017). Undergraduate student expectations of university in the United Kingdom: What 
really matters to them? [online]. Cogent Education. [Viewed 27 $7^{\text {th }}$ March 2019]. Available from: http://researchonline.ljmu.ac.uk/6041/1/Undergraduate\%20student\%20expec tations\%20of\%20university.pdf

Moser, C. (1988). The Robbins report 25 years after-and the future of the universities. Oxford Review of Education. 14(1), 5-20.

National Audit Office. (2004). Value for Money. [online] National Audit Office. [Viewed 27th March 2019]. Available from: https://www.nao.org.uk/successfulcommissioning/general-principles/value-for-money/

Nguyen, A. and Rosetta, J. (2013). Overcoming potential negative consequences of customer orientation in higher education: closing the ideological gap. Journal of Marketing for Higher Education. 23(2) 155-174.

Office of National Statistics (ONS) (2010). About ONS Busines Surveys. [online]. ONS. [Viewed 27 $7^{\text {th }}$ March 2019]. Available from: https://www.ons.gov.uk/surveys/informationforbusinesses/aboutonsbusinesss urveys

Office of the Independent Adjudicator. (2017). Annual Report. [online]. OIA. [Viewed 23 ${ }^{\text {rd }}$ June 2018]. Available from: http://www.oiahe.org.uk/media/121920/oia-annual-report-2017.pdf

Oliver, P. (2003). The Student's Guide to Research Ethics. Maidenhead: Open University Press. 
Olshavsky R. W. and Spreng, R. A.(1995). Consumer satisfaction and students:

Some pitfalls of being customer driven. Journal of Consumer Satisfaction,

Dissatisfaction, and Complaining Behavior, 8, 69-77.

Palfreyman, D., and Tapper, T. (2014). Reshaping the University: The rise of the regulated market in higher education. Oxford: Oxford University Press.

Palfreyman, D., and Tapper, T. (2016). The marketization of English higher education and the financing of tuition fees. London Review of Education. 14(1)

Parliament. (2018). Is there a market in higher education? [online]. Parliament. [Viewed 15 $15^{\text {th }}$ May 2018]. Available from: https://publications.parliament.uk/pa/cm201719/cmselect/cmtreasy/478/478 05.htm\#_idTextAnchor035

Pitman, T. (2000). Perceptions of academics and students as customers: A survey of administrative staff in higher education. Journal of Higher Education Policy and Management, 22(2), 165-175.

Robbins, Lord. (1963). Higher Education: Report of the committee. London: HMSO, Cmnd 2154.

Saunders, D. B. (2014). They do not buy it: exploring the extent to which entering first-year students view themselves as customers. Journal of Marketing for Higher Education. 1-24. 
Sharrock, G. (2000). Why students are not (just) customers (and other reflections on Life after George). Journal of Higher Education Policy and Management, 22(2), 149-164.

The Consumer Rights Act 2015.

The Daily Telegraph. (2012). Britain's best value universities. [online]. The Daily Telegraph. [Viewed 14 $4^{\text {th }}$ June 2018]. Available from: https://www.telegraph.co.uk/education/universityeducation/studentlife/9538463/Britains-best-value-universities.html Accessed 06.06.18

The Guardian. (2018). My students support our strike they don't want to be passive consumers. [online]. The Guardian. [Viewed $20^{\text {th }}$ July 2018]. Available from: https://www.theguardian.com/higher-educationnetwork/2018/mar/02/my-students-support-our-strike-they-dont-want-to-bepassive-consumers

The Institute for Teaching and Learning Innovation (ITALI). (2018). Students as Partners. [online]. The University of Queensland Australia. [Viewed 23 ${ }^{\text {rd }}$ July 2018]. Available from: http://itali.uq.edu.au/content/about-students-partners

The Telegraph. (2018). Revealed: Which degrees could earn you the highest graduate salary and the lowest. [online] The Telegraph. [Viewed $15^{\text {th }}$ May 2018]. Available from: https://www.telegraph.co.uk/education/2018/03/15/figuresreveal-stark-differences-earning-potential-graduates/

Thomas, D. (2006). A General Inductive Approach for Analyzing Qualitative Evaluation Data. American Journal of Evaluation. 27(2) 237-246. 
Titus, J. J. (2008). Student ratings in a consumerist academy: Leveraging pedagogical control and authority. Sociological Perspectives, 51(2), 397-422.

Tomlinson, M. (2017). Student perceptions of themselves as 'consumers' of higher education. British Journal of Sociology of Education. 38(4), 450-467.

Trow, M. (1973). Problems in the Transition from Elite to Mass Higher Education. Berkley, CA: Carnegie Commission on Higher Education.

University College Union. (2010). The impact of student satisfaction surveys on staff in HE and FE institutions. [online]. UCU. [Viewed $11^{\text {th }}$ June 2018]. Available from: https://www.ucu.org.uk/brief_satissurveys

Walford, G. (1991). Doing Educational Research. London: Routledge.

Watson, D. and Taylor, D. (1998). Lifelong Learning and the University: A PostDearing Agenda. London: Falmer.

Wilkins, S., Balakrishnan, M. S., \& Huisman, J. (2012). Student choice in higher education motivations for choosing to study at an international branch campus. Journal of Studies in International Education. 16(5), 413-433.

Wiles, R, Crow, G, Heath, S and Charles, V. (2006). Anonymity and Confidentiality. [online]. ESRC National Centre for Research Methods : NCRM Working Paper Series 2/06 [Viewed $10^{\text {th }}$ July 2018]. Available from: http://eprints.ncrm.ac.uk/423/1/0206_anonymity\%2520and\%2520confidential ity.pdf 
Williams, J. (2010). Constructing Students: consumer or participants? Paper presented at Higher Education Close Up 5, University of Lancaster, July.

Williams, J. (2013). Consuming Higher Education: Why Learning Can't be Bought. London: Bloomsbury.

Woodall, T., Hiller, A., and Resnick, S. (2014). Making sense of higher education: students as consumers and value of the university experience. Studies in Higher Education. 39(1) 48-67. 